\title{
Aktualisasi Hukum Agraria Guna Menunjang Otonomi Daerah
}

\author{
Winahyu Erwiningsih
}

\begin{abstract}
The Enactmen of Regional Autonomy for the Huge land territory to the district Area is basically stated as the claim of reformation. It also become the main clue for the regional autonomy. Both of them were endorsed in the Basic Principle of Agrarian Law (UUPA). The land territory in the whole nation was revealed and endorsed in the form of justice to the society in this regulation. It also have another main purpose a for the growth of prosperity. But in fact, the condition of land territory is being far from the basic purpose and claim. The question now is all about the eficiency of Basic Principle of Agrarian Law to hold the regional autonomy.
\end{abstract}

\section{Pendahuluan}

Akhir-akhir ini timbul gejala perseorangan, golongan masyarakat bahkan institusi pemerintah menuntut hak-hak atas tanah. Tuntutan itu tidak saja dilakukan antar mereka, namun juga antara segolongan masyarakat dengan pemerintah dan pemerintah dengan pemerintah. Tidak jarang cara yang dilakukan menimbulkan konflik sosial bahkan mengancam disintegrasi bangsa.

Untuk meredam gejolak tersebut Pemerintah memberlakukan Undang-undang Nomor 22 Tentang Pemerintah Daerah berisi pemberian otonomi secara luas, nyata dan bertanggung jawab kepada Kabupaten.

Apakah yang mendasari diperlukannya otonomi daerah dalam masalah pertanahan? Apakah pemberian otonomi yang demikian itu mampu memecahkan gejolak pertanahan yang terjadi? Faktor-faktor apakah yang perlu diperhatikan dalam melaksanakan otonomi di daerah khususnya berkaitan dengan pengelolaan tanah.

Tulisan berikut akan membahas aspek hukum kewenangan atas tanah antara wewenang negara dengan pemerintah daerah, faktor-faktor yang dipandang urgen di daerah yang berpengaruh dalam penyelesaian pertanahan, dimaksudkan sebagai acuan bagi pemerintah daerah dalam mengatur penggunaan tanah di wilayahnya.

Hubungan Tanah dengan Negara, Perseorangan dan Masyarakat

Para ahli hukum yang mendasarkan diri pada hukum alam percaya bahwa secara 
kodräti untuk melangsungkan hidup seseorang itu memeriukan pemilikan atas sesuatu. Jika seseorang telah dipenuhi pemilikannya, maka hidup akan menjadi tertib karena tidak ada alasan lagi untuk saling mengganggu. Tanah menurut aliran ini merupakan salah satu objek pemilikan baik oleh perseorangan maupun masyarakat. Negara dengan demikian bukan sebagai pemilik (privat) atas tanah sebab pemilik atas tanah adalah manusia alami. Thomas Aquinas sebagaimana dikutip oleh Iman Soetiknjo' mengemukakan alasanalasannya mengapa setiap orang lebih suka sesuatu menjadi miliknya sendiri, sehingga tidak perlu menyerahkan sesuatu itu pada orang lain, karena jika sesuatu ada pada diri sendiri, maka tidak akan terjadi kekacauan. Masyarakat akan hidup damai karena kepentingannya telah terpenuhi. Sedangkan terhadap tanah tak bertuan atau tanah masyarakat hukum yang diduduki oleh warga masyarakat terjadi sebagai bagian dari sifat keteraturan pola pemilikan tanah individual. ${ }^{2}$ Pencabutan hak individu atas tanah oleh negara yang berdasarkan pada undang-undang, merupakan gambaran kuatnya pengakuan hak individu atas tanah tersebut.

Penempatan hak-hak manusia sedemikian itu, memperlihatkan kuatnya kedudukan manusia alami atas tanah, sehingga dapat mengecualikan pemilikan tanah oleh negara dengan menempatkan bahwa seolah-olah. hak-hak individu manusia itu merupakan hak yang suci tak tersentuh dengan kepentingan masyarakatnya. Masalahnya adalah: Bagaimanakah kedudukan negara atas tanah itu? Menurut pendapat aliran di atas, memang tidak tampak tegas dalam pengertian bahwa negara mungkin tidak dapat memiliki tanah dalam pengertian milik (eigendom) yang berisi kekuasaan mutlak atas tanah. Namun negara mungkin dapat menguasai tanah (tanpa harus memiliki) untuk kepentingan publik.

Berlainan dengan paham yang dianut oleh pengikut aliran hukum alam di atas, Ulpianus dan Vegting sebagaimana dikutip oleh Ronald Z Titarelu menyatakan bahwa negara berdasarkan hubungan khusus dapat memiliki tanah (walaupun semu sifatnya). Pemilikan tanah itu dipergunakan untuk umum (res publica). Hubungan hukum yang terjadi dapat bersifat pemilikan ataupun penguasaan. ${ }^{3}$ Implementasinya adalah bahwa terhadap tanah-tanah yang dipergunakan langsung oleh negara, dapat dimiliki oleh negara. Negara juga mempunyai kewenangan untuk mengatur terhadap tanah-tanah yang dipergunakan oleh umum yang dipandang dapat memberikan manfaat lebih dibandingkan dimiliki oleh masyarakat.

Senada dengan pendapat tersebut ialah pendapat yang mendasarkan pada teori hukum perjanjian masyarakat yang dikemukakan oleh Jean Jacques Rousseau serta pendapat

'Iman Soetiknjo. 1983. Politik Agraria Nasional, Hubungan Manusia dengan Tanah berdasarkan Pancasila. Yogyakarta: Gajahmada University Press. HIm. 11.

2lbid, hlm. 13.

${ }^{3}$ Ronald Z Titarelu. 1993. Penetapan Asas-asas Hukum Umum Dalam Penggunaan Tanah Untuk Sebesar-besarnya Kemakmuran Rakyat. Disertasi. Pasca Sarjana. Universitas Airlangga. HIm. 105-106. 
M. Kaser dan P.B.J. Wubbe. ${ }^{4}$ Pendapat ini menyatakan bahwa milik perseorangan atas tanah diserahkan berdasarkan perjanjian masyarakat yang dijelmakan dengan hukum. Dalam kehidupan bemegara, selunuh kekayaan yang ada dalam negara adalah milik publik yang dikuasai oleh hukum negara. Hal ini berlaku pula terhadap setiap hubungan hukum, di mana salah satunya adalah negara, sehingga negara mempunyai kewenangan hukum atas kepunyaan negara.

Dengan demikian pemilikan atas tanah oleh negara mengandung kategori-kategori sebagai berikut:

a Negara tidak memiliki tanah, tapi secara khusus mempunyai hubungan dengan tanah khususnya berkaitan dengan kepentingan umum;

b Negara sebagai satu-satunya pemilik tanah baik dalam arti sepenuhnya maupun dalam arti sebagai mempunyai;

c Negara memiliki tanah di samping milik orang perseorangan;

d Negara menjalankan kekuasaan atas tanah yang dimiliki oleh masyarakat, seolah-olah tanah adalah miliknya.

Dalam kenyataannya dapat terjadi bahwa negara memiliki sepenuhnya atas tanah di wilayah negara tersebut seperti di negaranegara komunis bekas Uni Sovyet dan Republik Rakyat Cina. Demikian pula dapat terjadi di samping milik perseorangan, Negara juga memiliki tanah dalam bentuk domein privat (milik para raja) dan domein publik (untuk umum) baik yang dipergunakan untuk kepentingan (pemerintahan) negara sendiri, maupun domein publik dalam artian dipergunakan untuk umum seperti jalan dan sungai. Demikian pula kenyataannya terdapat tanah-tanah domein kotapraja dengan kekuasaan bersifat administratif.

Dengan demikian, negara dapat bertindak atas tanah baik dalam bentuk pemilikan atau seperti milik (dikuasai secara administratif). Hal itu terjadi karena:

a) sifat tanah yang tidak dapat dimiliki oleh perseorangan atau memang tidak mempunyai pemilik;

b) Fungsi tanah yang secara langsung berguna bagi masyarakat;

c) Mempunyai kemanfaatan umum, serta

d) Tanah dipergunakan sendiri oleh negara.

Pelaksanaan campur tangan negara atas tanah tersebut dapat dilakukan oleh pemerintah daerah menurut bentuk negara serta kemauan politik yang dianut. Demikian pula perseorangan dan golongan masyarakat dapat memiliki tanah, baik menurut kodratnya maupun atas perjuangannya untuk memperoleh tanah. Perseorangan juga dapat hanya memiliki hak pakai atas tanah kesemuanya.

\section{Hubungan Tanah Dengan Negara, Masyarakat dan Perorangan Menurut Pembukaan UUD 1945}

Dasar konstitusi yang dapat dipergunakan dalam pengaturan masalah tanah di Indonesia adalah Pasal 33 ayat (3) UUD 1945. Pasal

“Kaser, Drt M-Wubbe, Mr. F.B.J. 1967. Romeins Privaatstrecht, N.V. Uitgeverijmaatschappij W.E.J. Tjeenk Willink.Amsterdam: Zwolle. Hlm. 94 (terjemahan bebas oleh penulis). 
tersebut menyatakan bahwa Bumi dan air dan kekayaan alam yang terkandung didalamnya dikuasai oleh negara dan dipergunakan untuk sebesar-besarnya kemakmuran rakyat.

Kalimat tersebut di atas akan bermakna jika dipahami keseluruhan maksud dan tujuannya. Pengertian "dan" bukan merupakan kehendak yang dituju.

Atas dasar pemaknaan demikian itu, maka secara teoritik kepentingan untuk mencapai sebesar-besar kemakmuran rakyat merupakan dasar bagi dikuasainya tanah oleh negara. Persoalannya adalah mengapa negara harus menguasai?

Kemakmuran rakyat tidak akan tercapai jika satu sama lain tidak mempunyai kesamaan persepsi tentang bagaimana hidup yang baik atau makmur itu. Berkaitan dengan tanah, hidup yang baik itu memerlukan pola keteraturan tentang cara-cara memenuhi kehidupan secara baik. Agar pola keteraturan dapat terjelma, perlu adanya kecakapan atau kekuasaan untuk menjelmakan. Kekuasaan itu diberikan kepada Negara sebagai organisási masyarakat tertinggi dalam suatu wilayah. Hal demikian sesuai dengan anggapan dan kenyataan bahwa manusia itu hidup dalam dimensi-dimensi perseorangan, masyarakat dan negara, sehingga tanah tidak saja dimiliki (baca: dipergunakan) oleh perseorangan atau masyarakat saja. Negara juga memiliki kekuasaan atas tanah. Malahan Negara mempunyai kewenangan untuk mengatur semua hubungan hukum atas tanah agar berbagai dimensi kebutuhan masyarakat secara perorangan maupun kelompok terpenuhi. Manakah yang lebih diutamakan kemakmuran perseorangan, masyarakat ataukah negara?Alinea ke-4 Pembukaan UUD 1945 merumuskan bahwa Negara berdasar atas keTuhanan Yang Maha Esa menurut Dasar Kemanusiaan yang Adil dan Beradab dalam kerangka Negara Kesatuan Republik Indonesia.

Dari rumusan tersebut memperoleh pandangan bahwa untuk mengatur kebutuhan masyarakat, negara tidak semata-mata sebagai organisasi kekuasaan yang bersumber pada kedaulatan rakyat. Kebutuhan rakyat untuk sejahtera juga diatur oleh hukum Tuhan, hukum yang memberikan kepada manusia karunia atas tanah. Namun demikian, Tuhan tidak serta merta memberikan haknya kepada manusia, sebab cara demikian akan menjerumuskan pada jurang kebodohan, ketidakpahaman tentang odrat lilahi. Oleh karena itu Tuhan sekaligus juga membebani dengan kewajiban untuk menjaga dan memeliharanya.

Dàlam hubungan manusia, menempatkan tindakan manusia itu seimbang antara hak dan kewajibannya. Sikap demikian identik sebagaimana Tuhan memberikan manusia (untuk sebesar-besarnya) menikmati karuniaNya sebagai hak dengan mengharuskan melaksanakan kewajiban dalam memenuhi karunia-Nya itu. Sehingga kemakmuran yang akan dicapai adalah kemakmuran manusia yang adil dan beradab yaitu yang menyadari dirinya dan orang lain sama-sama sebagai makhluk Tuhan. Menyadari dalam hubungan antar perilaku manușia itu tidak saja memperjuangkan haknya semata, tetapi juga kewajiban kepada Tuhan, kepada sesama, menurut nilai-nilai moral ke-Tuhanan, kemasyarakatan. Oleh Soepomo dikiaskan dengan persatuan kawulo-gusti, dunia luar dan dunia batin, mikro kosmos dan makro kosmos, antara rakyat dan pimpinannya serta keseimbangan lahir batin karena manusia baik 
sebagai pribadi, golongan atau masyarakat mempunyai pergaulan hidupnya sendiri tetapi saling terkait pengaruh mempengaruhi. ${ }^{5} \mathrm{Hal}$ ini akan berbeda dengan landasan moral sebagaimana dikemukakan oleh G.W. Friedrich Hegel yang menempatkan hak manusia pribadi hanya sebagai bagian dari hak masyarakat secara keseluruhan, walaupun manusia pribadi diakui mempunyai kedudukan yang sangat penting, atau pendapat Immanuel Kant yang mengedepankan kepentingan manusia individu sehingga memandang sesuatu itu dipertukan manusia karena semata-mata sebagai manusia.

Nilai-nilai moral dalam bentuk keseimbangan hak dan kewajiban yang hidup sebagai diri pribadi, masyarakat dan bangsa merupakan asas hukum yang dijunjung tinggi. Berkaitan dengan tanah, mengandung pula arti bahwa tanah merupakan pemberian Tuhan kepada pribadi, keluarga, masyarakat dan bangsa Indonesia. Memiliki tanah yang diturunkan dari Tuhan mengandung arti memiliki kewajiban untuk memanfaatkan secara adil dan beradab bagi kepentingan diri pribadi, keluarga, masyarakat dan bangsa menurut keseluruhan harkat dan martabat sebagai makhluk ciptaan Tuhan. Sehingga kemampuan dan kecakapan memanfaatkan tanah dijalankan atas dasar ini, bukan sematamata karena dirinya sebagi manusia dengan segala nafsu dan keterbatasannya.

Dengan demikian yang memiliki hubungan dengan tanah adalah manusia secara alamiah yakni perseorangan, keluarga, masyarakat kesemuanya mempunyai kedudukan yang seimbang mengingat sifat penggunaan tanah akan juga bermuara pada kepentingan/ kepuasan manusia perseorangan. Kumpulan dari keseluruhan pemilikan tersebut disebut sebagai milik bangsa.

\section{Penyelenggaraan Kekuasaan Negara Atas Tanah}

Negara sebagai organisasi suatu bangsa diberikan kekuasaan oleh rakyat berdasarkan hukum (konstitusi) untuk mengatur berbagai kekuasaan apapun dalam masyarakat. Oleh Van Apeldoorn digambarkan sebagai suatu kekuatan (macht) yang teratur oleh hukum yang berdasarkan kesusilaan.

Kekuasaan negara yang demikian, di indonesia memiliki dasar dan bentuk dalam Pokok Pikiran ke-2 Pembukaan UUD 1945 yaitu; Negara yang berdaulat atas dasar permusyawaratan rakyat.

Rumusan demikian mengandung makna bahwa permusyawaratan/perwakilan berlandaskan hikmah kebijaksanaan dalam pengambilan keputusan merupakan cara penyelenggaraan negara yang terbaik. Anggapan dasarnya ialah bahwa melalui cara demikian, akan lahir wujud kepentingan dan kemanfaatan bersama yang memenuhi keluhuran harkat dan martabat. Kepentingan dan kemanfaatan bersama atas dasar nilainilai kemanusiaan (secara formil terwujud dalam hukum) guna mewujudkan keadilan sosial bagi seluruh rakyat Indonesia serta untuk melindungi segenap bangsa dan seluruh tumpah darah Indonesia berdasarkan

5Muhammad Yamin. Naskah Persiapan Undang-Undang Dasar 1945. Dijlid 1. Cetakan ke 2. Jakarta: Penerbit Siguntang., HIm. 113. 
persatuan sebagai sesuatu yang akan diatur oleh negara. Apa yang dikemukakan di atas mendasari pola hubungan hukum antara manusia, keluarga, masyarakat dan bangsa berkaitan dengan tanah dengan menempatkan negara sebagai organ yang diberi kekuasaan untuk mengaturnya.

Tanah sebagai sumber daya alam strategis bagi bangsa memerlukan. campur tangan negara untuk mengaturnya. Campur tangan mana tunduk pada lingkup pengaturan yang demikian itu.

Jadi hubungan perseorangan, keluarga dan masyarakat dengan tanah didasarkan atas fitrahnya sebagai makhluk Tuhan, untuk hidup secara individu maupun sosial dengan menjalankan hak (kemampuan dan kecakapan) dan kewajiban (keharusan) secara seimbang demi keadilan dan kemanfaatan individu, keluarga dan masyarakat.

Sedangkan hubungan antara negara dengan tanah ialah di samping atas dasar kedaulatan negara, juga didasarkan atas hukum pada kedaulatan rakyat demi tercapainya keseimbangan hak dan kewajiban yang adil bagi seluruh bangsa, mendatangkan sebesar-besamya manfaat bagi rakyat. Negara dengan demikian tidaklah didudukkan sebagai pemilik, namun sebagai organ penguasa yang diberi kekuasaan (secara hukum) untuk menjamin pelaksanaan peruntukan tanah sesuai dengan tujuan yang dimaksud.

\section{Hubungan Tanah Dengan Otonomi Daerah}

Di atas telah dikemukakan bahwa agar tanah (sebagai karunia Tuhan) dapat dijadikan sarana hidup sejahtera, maka manusia Indonesia harus memahami dirinya sebagai makhluk individu dan sosial yang mendasarkan atas keadilan dan kemanfaatan tanah bagi kepentingan perseorangan maupun masyarakat. Kesemuanya dapat dicapai jika ada pihak yang berwenang mengatumya yakni negara sebagaimana ditentukan dalam Pasal 33 ayat (3) UUD 1945.

Pengertian dan penjabaran Pasal 33 ayat (3) UUD 1945 terumuskan dalam Pasal 2 UUPA, selengkapnya berbunyi:

1. Atas dasar ketentuan dalam Pasal 33 ayat (3) Undang-Undang Dasar dan hal-hal sebagaimana dimaksud dalam Pasal 1 , bumi, air dan ruang angkasa, termasuk kekayaan alam yang terkandung di dalamnya itu pada tingkatan tertinggi dikuasai oleh negara sebagai organisasi kekuasaan seluruh rakyat.

2. Hak menguasai dari negara termaksud dalam ayat (1) pasal ini memberi wewenang untuk:

a) mengatur dan menyelenggarakan peruntukan, penggunaan, persediaan dan pemeliharaan bumi, air dan ruang angkasa tersebut;

b) menentukan dan mengatur hubungan-hubungan hukum antara orang-orang dengan bumi, air dan ruang angkasa;

c) menentukan dan mengatur hubungan hukum antara orang-orang dan perbuatan-perbuatan hukum yang mengenai bumi, air dan ruang angkasa.

3. Wewenang yang bersumber dari hak menguasai dari negara tersebut pada ayat 2 pasal ini digunakan untuk mencapai sebesar-besar kemakmuran rakyat dalam arti kebangsaan, kesejahteraan dan 
kemerdekaan dalam masyarakat dan negara hukum Indonesia yang merdeka, berdaulat, adil dan makmur.

4. Hak menguasai dari negara tersebut di atas pelaksanaannya dapat dikuasakan kepada Daerah-daerah Swatantra dan masyarakat-masyarakat hukum adat, sekedar diperlukan dan tidak bertentangan dengan kepentingan nasional, menurut ketentuan-ketentuan Peraturan Pemerintah. ${ }^{6}$

Dari pengertian tersebutjelas bahwa Negara adalah pihak berkuasa, diberi kekuasaan oleh rakyat tidak untuk memilikj atau mempergunakan tanah semata-mata untuk keperluannya sendiri, tapi untuk mengatur penggunaan dan peruntukan tanah agar tercipta kemakmuran rakyat secara meningkat dan merata. Persoalannya adalah: Apakah hak untuk mengatur peruntukan tanah semata-mata ditentukan oleh Negara dalam arti Pemerintah Pusat?

Pemberian kekuasaan pada negara sepenuhnya akan mengakibatkan terjadinya pemerintahan sentralistik yang cenderung otoriter. Pemerintahan demikian dapat melemahkan sendi-sendi tatanan masyarakat seperti demokrasi, pemerataan dan keadilan. Oleh karena itu agar tidak terjadi kesewenangwenangan harus dilakukan desentralisasi kekuasaan, dalam arti pembentukan satuansatuan pemerintahan yang lebih rendah yang diberi hak mengatur dan mengurus sendiri sebagian urusan pemerintahan (negara) sebagai urusan rumah tangganya, namun tetap dalam satu susunan negara kesatuan dengan tugas masing-masing meskipun diakui dapat terjadi tarik menarik bahkan spanning hubungan antara keduanya.

Lebih khusus Bagir Manan menguraikan perlunya diadakan desentralisasi:

a) Sebagai cerminan dari ciri kerakyatan yang mengedepankan sikap arif bijaksana dalam memecahkan segala sesuatu secara musyawarah. Musyawarah dilakukan sebagai wujud keikutsertaan rakyat dalam penyelenggaraan pemerintahan di tingkat daerah dengan memberi wewenang, tugas dan tangung jawab untuk mengatur dan mengurus kepentingan-kepentingan rumah tangganya daerah sendiri dengan secara bebas melakukan berbagai prakarsa (inisiatif) dalam batas-batas ketentuan yang berlaku.

b) Untuk lebih memberikan penghargaan atas pemerintahan asli yang telah ada sejak dahulu baik dalam bentuk pemerintahan otonom, swapraja maupun pemerintah desa. Tentu saja bentuk pemerintahan tersebut harus disesuaikan dengan kemajuan bangsa;

c) Lebih menghargai akan kebhinnekaan bangsa baik dari segi ekonomi, sosial, budaya dan kepercayaan. Kebhinnekaan itu menimbulkan hajat hidup dan kebutuhan yang berbeda dari daerah satu dengan lainnya. Rakyat setempatlah yang mengetahui akan kebutuhan mereka. Ini sesuai dengan prinsip keadilan sosial bagi seluruh bangsa Indonesia;

${ }^{6}$ Boedi Harsono. 1996. Hukum Agraria Indonesia, Himpunan Peraturan-peraturan Hukum Tanah. Cetakan ketiga belas. Jakarta: Penerbit Djambatan. Hlm. 5-6. 
d) Sesuai dengan prinsip Negara hukum - yang demokratis di mana kekuasaan pusat dibatasi berdasarkan kedaulatan rakyat. Salah satu bentuknya ialah dengan cara pemencaran kekuasaan badan-badan kenegaraan meliputi tugas administratif dan tugas legislasi utamanya terhadap masalah-masalah penting bagi daerah.

Keseluruhan alasan periunya dilakukan desentralisasi pemerintahan negara itu adalah untuk mewujudkan keadilan dan kesejahteraan sosial di daerah yang pada hakekatnya juga merupakan tugas dan tujuan pemerintah pusat.

Berdasarkan alasan tersebut dapatlah dipahami bahwa pelaksanaan kekuasaan negara atas tanah sebagaimana terumus dalam ayat (4) di atas "dapat" dilaksanakan pula oleh pemerintah daerah dan masyarakat hukum lainnya, segala sesuatunya tergantung pada pertimbangan kepentingan kemanfaatan akan tanah. Kedudukan pemerintah daerah dalam hal ini bertindak sebagai pelaksana kekuasaan negara atas tanah tidak bersifat asli karena diberikan wewenang untuk itu. Oleh karena itu pemerintah daerah harus bertindak atas dasar asas taat asas terhadap ketentuan normatif ketatanegaraan Indonesia.

Apa yang dimaksud dengan otonomi dapat diberikan corak yang bermacam-macam seperti otonomi riil, otonomi luas dan otonomi nyata, segala sesuatunya bergantung pada kemauan politik negara serta berdasarkan ajaran yang dianut oleh negara untuk memilih dan mengartikannya bentuk otonomi pada daerahnya.

Dalam pada itu Pasal 2 ayat (4) UUPA ini secara umum masih bersifat "kemungkinan" segala sesuatunya tergantung pada pusat tanpa mempunyai pedoman yang jelas perihal sejauh mana batas-batas pelimpahan pelaksanaan kekuasaan negara atas tanah itu diserahkan kepada derah dan masyarakat hukum adat?

Undang-undang Nomor 22 tahun 1999 tentang pemerintah Daerah secara umum berisi penegakan adanya pelimpahan pelaksanaan kekuasaan negara atas tanah tersebut di atas.

Pasal 4 ayat (1) jo. Pasal 5 ayat (1) dan (4) Undang-undang Nomor 22 Tahun 1999 merumuskan bahwa dalam rangka pelaksanaan asas desentralisasi dibentuk dan disusun Daerah Propinsi, Daerah Kabupaten dan Daerah Kota yang berwenang mengatur dan mengurus kepentingan masyarakat setempat menurut prakarsa sendiri berdasarkan aspirasi masyarakat, dengan tetap mempertimbangkan kemampuan otonomi, potensi daerah, sosial budaya, sosial politik, jumlah penduduk, luas daerah, dan perimbangan lain yang memungkinkan terselenggaranya otonomi daerah.

Lebih lanjut Pasal 7 ayat.(1) jo. Pasal 11 jo. Pasal 2 Peraturan Pemerintah Nomor 25 tahun 1999 menyatakan bahwa kewenangan Daerah Kabupaten dan Daerah Kota mencakup semua kewenangan pemerintahan. Salah satunya yang wajib dilaksanakan ialah bidang pertanahan.

Dengan demikian Pemerintah Daerah dan Daerah Kota wajib melaksanakan kéwenangan untuk:

a) Mengatur mengenai persediaan, penggunaan dan peruntukan tanah di wilayahnya baik untuk kepentingan manusia perseorangan, kepentingan sosial, keagamaan, kepentingan ekonomi, 
pertanian, industri, serta kepentingan daerah dan negara;

b) Melakukan perencanaan penggunaan tanah yang meliputi penggunaan atas ruang di atas dan di bawah tanah sesuai dengan batas-batas peruntukannya;

c) Mengatur pola hubungan antara tanah dengan manusia warga dengan penduduk di daerah;

d) Mengatur hubungan antara manusia dengan manusia berkaitan dengan tanah di wilayahnya termasuk mempersiapkan kelembagaannya agar hubungan hukum yang terjadi dapat terjamin pemenuhannya.

Dalam melaksanakan kewenangan tersebut Pemerintah Daerah dan Daerah Kota harus memperhatikan:

a) Ketentuan peraturan perundang-undangan yang berlaku berkaitan dengan tanah berdasarkan asas taat asas;

b) Dalam pembuatan peraturan daerah sejauh mungkin melibatkan unsur-unsur legislatif daerah menurut kewenangan yang ada;

c) Aspek keadilan sosial serta pemanfaatannya yang dapat menjamin peningkatan kesejahteraan;

d) Penghargaan secara proporsional terhadap unsur-unsur kebudayaan asli daerah berkaitan dengan nilai dan fungsi tanah;

\section{Agenda Masalah Tanah Di Daerah}

Pemberian otonomi yang luas atas tanah kepada Daerah Tingkat II dan Daerah Kota untuk memenuhi tuntutan reformasi serta arahan sebagaimana terumuskan dalam Undang-undang Pokok Agraria di mana penguasaan tanah di seluruh wilayah tanah air ini diatur secara adil dan merata sehingga kesejahteraan dapat dicapai.

Dalam kenyataannya kondisi penguasaan tanah pada saat ini adalah jauh dari tuntutan dan arahan tersebut.

Di bidang pertanian, terdapat sedikit orang yang menguasai tanah terlampau luas, sedangkan di lain pihak banyak petani yang tidak mempunyai tanah atau tanahnya sempit. Di samping itu banyak bidang-bidang tanah pertanian yang dikuasai atau dimiliki oleh bukan petani.

Di bidang perkebunan, banyak penguasaan tanah luas dengan Hak Guna Usaha dikelola hanya sampai pada taraf pembukaan lahan dan pengajuan persyaratan memperoleh kredit. Demikian pula tidak sedikit penyelenggaraan perkebunan bersinggungan dengan tanah-tanah hak masyarakat desa atau kesatuan masyarakat hukum setempat berakibat timbulnya konflik pertanahan berkepanjangan.

Di kawasan pembangunan, ijin lokasi yang semula dimaksudkan sebagai upaya untuk mengendalikan pemanfaatan tanah, di beberapa tempat justru dijadikan alat untuk menekan rakyat pemilik tanah untuk menyerahkan tanahnya kepada perusahaan pemegang ijin lokasi, sehingga pemilik tanah yang termasuk dalam area ijin lokasi tidak dapat lagi melaksanakan hak-haknya sebagai pemilik suatu hak atas tanah.

Dilihat dari segi apapun keadaan ini mencerminkan adanya ketimpangan masalah keadilan dalam pemilikan dan penguasaan tanah yang berakibat pada rendahnya kesejahteraan rakyat.

Dalam pada itu di beberapa tempat masih terdapat kesatuan masyarakat hukum adat 
yang mempunyai hubungan kuat dengan tanah. Dalam pándangannya, tanah merupakan sumber kehidupan yaitu tempat dijadikannya lahan produksi dan minum; tanah sebagai tempat berkumpul bersama mengembangkan rasa sosial dan ketentraman batin. Tanah di wilayah persekutuan itu diatur menurut aturan adat dan dijaga para ketua adat. 'Hak-hak atas tanah yang ada bukan bersifat privat atau publik, tetapi merupakan sekumpulan hak perseorangan, keluarga, masyarakat bahkan hak orang asing dengan berbagai nama seperti hak pakaj, hak menggarap, hak membuka tanah, hak ulayat dan sebagainya. Masalah yang dapat menimbulkan kesulitan adalah bagaimanakah menentukan bahwa suatu persekutuan hukum adat itu masih ada? Sejauh mana batas-batas penguasaan atas tanah akan diakui? Bagaimana pola hubungan yang adil dapat diciptakan baik antara warga masyarakat hukum adat sendiri maupun antara warga dengan bukan warga? . .

Dari sisi peraturan perundang-undangan yang ada masih banyak berbagai corak pengaturan yang beraneka ragam. Terdapat peraturan yang diperintahkan oleh undangundang, tetapi belum dilengkapi peraturan pelaksanaannya. Terdapat pula peraturan yang berderajat sama di mana satu dengan lainnya saling bertentangan, bahkan masih banyak yang belum lengkap. Salah satunya adalah sebagaimana ditegaskan dalam Pasal 7 ayat (2) Undang-undang Nomor 22 tahun 1999 serta penjabarannya dalam Peraturan Pemerintah Nomor 25 tahun 2000. Dalam peraturan itu dirumuskan bahwa kewenangan bidang pemerintahan, khususnya bidang pertanahan saat ini sangatlah luas namun tidak boleh melanggar kebijaksanaan perencanaan nasional dan pengendalian pembangunañ nasional secara makro. Kebijaksanaan 'itu meliputi kewenangan (campur tangan) Pemerintah Pusat dalam hal:

a) Penetapan persyaratan pemberian hakhak atas tanah;

b) Penetapan persyaratan landreform;

c) Penetapan standar, administrasi pertanahan;

d) Penetapan pedoman biaya pelayanan pertanahan;

e) Penetapan kerangka dasar kadastral nasional dan pelaksanaan pengukuran kerangka dasar kadastral nasional orde I dan II.

f) Penetapan pedoman untuk menentukan - standar pelayanan minimal dalam bidang pertanahan;

g). Penetapan kriteria penentuan dan perubahan fungsi ruang kawasan atau lahan dalam rangka penyusunan tata ruang.

Kesemuanya penetapan itu dijabarkan lebih lanjut melalui Peraturan Menteri. Dalam kenyataannya, peraturan menteri yang dimaksud belum ada sehingga yang dipakai. saat ini adalah peraturan lama yang masih berlaku.

Salah satu peraturan berkaitan dengan kewenangan Pemerintah Daerah dan Daerah Kota adalah peraturan tentang pemberian hak atas tanah sebagaimana diatur dalam Peraturan Menteri Dalam Negeri Nomor 6 Tahun 1972 tentang Pelimpahan Wewenang Pemberian Hak Atas Tanah. Pasal 7 s/d 9 Peraturan tersebut menentukan wewenang Bupati/Walikota untuk:

a) Memberi keputusan mengenai permohonan ijin untuk memindahkan hak milik; 
b) Memberi keputusan mengenai permohonan ijin memindahkan hak guna bangunan atas tanah negara pada warga negara Indonesia atau badan hukum Indonesia yang bukan bermodal asing;

c) Memberi keputusan mengenai permohonan jijn untuk memindahkan hak pakai atas tanah negara kepada warga negara indonesia atau badan hukum/ Indonesia yang bukan bermodal asing;

d) Memberi keputusan permohonan ijin untuk membuka tanah, jika luasnya lebih dari 2 (dua) ha tetapi tidak lebih dari 10 (sepuluh) ha.

Isi peraturan tersebut sangat membatasi kewenangan Bupati/Walikota dalam melaksanakan tugasnya sebagai Kepala Daerah Otonom.

Pemberian wewenang tersebut juga mengingkari permasalahan yang ada di daerah dimana pemindahan hak dapat pula terjadi dari hak milik ke hak guna bangunan, hak pakai atau hak guna usaha dan sebaliknya, baik atas tanah-tanah yang telah mempunyai hak (bukan tanah negara) maupun terhadap tanah-tanah yang belum serta baik untuk kepentingan perseorangan maupun badan hukum seperti yang banyak terjadi pada pembangunan kawasan Industri dan kawasan pembangunan perumahan.

Di samping itu, dalam praktiknya, yang banyak terjadi di daerah adalah perselisihan penguasaan dan penggunaan tanah dalam dimensi yang lebih luas, (jadi belum sampai kepada proses penuntutan pemilikan secara administratif). Sebagai contoh perselisihan antara segolongan warga masyarakat dengan perụsahaan perkebunan. Perselisihan tersebut dapat bersifat horizontal yang berskala luas mengingat akar masalahnya tidak saja tentang penentuan batas-batas tanah garapan atau tanah ulayat desa dengan pengelolaan tanah perkebunan, tetapi juga tentang pemanfaatan hasil-hasil tanah yang tidak melibatkan penduduk sekitar. Dalam hal demikian.

Sedikit gambaran permasalahan pertanahan yang telah dan akan menjadi beban daerah menggambarkan betapa pemerintah daerah akan menerima beban permasalahan yang berat tetapi substansial bagi kepentingan warganya. Oleh karena itu prioritas perlu diberikan agar penanganan masalah dapat terselesaikan sesuai kemampuan.

Menurut pendapat penulis prioritas yang perlu ditangani:

1. Melakukan inventarisasi tanah serta hakhak yang melekat pada tanah di daerahnya;

2. Melakukan dialog dengan masyarakat adat untuk mencari masukan tentang kedudukan dan peran masyarakat hukum adat dalam masalah tanah di daerahnya;

3. Meredam konllik pertanahan yang terjadi terutama yang berkaitan dengan industri strategis;

4. Melakukan perencanaan dalam pola pengaturan tata ruang daerah menghendaki peruntukan dan penggunaan tanah di daerahnya;

5. Melakukan evaluasi atas peraturan hukum tanah utamanya berkenaan pada bidang-bidang yang netral.

\section{Simpulan}

Angin segar otonomi bagi daerah hendaknya benar-benar dapat dimanfaatkan sesuai dengan iklim reformasi kehidupan bernegara yang sedang bersemi. Nilai-nilai 
kesusilaan, demokrasi, supremasi hukum dan hak asasi manusia hendaknya dikedepankan dengan memegang teguh asas-asas hükum ketatanegaraan dan pemerintahan yang dianut serta diimbangi dengan transparansinya rumusan kebijakan dan profesionalitas aparat dan pemerintahan daerah. Meninggalkan nilai-nilai tersebut di atas sama saja dengan menciptakan kekuasaan otoriter baru di daerah yang pasti melahirkan bentuk ketidakadilan dan kesengsaraan di masyarakat.

UUPA yang ada dapat dipakai sebagai dasar landasan pengaturan, tanpa perlu berobsesi menggantinya. Penjabaran pelaksanaannya dirumuskan dalam peraturan daerah secara arif dan bijaksana.

\section{Daftar Bacaan}

Apeldom, L.J. van. 1985. Bewerkt door Dijk; p.van, Inleidind tot de studie van Nederlanse Recht. W.E.J. Tjeenk . Willink, Zwolle, Achitiend, Druk..

Manan, Bagir: 1993: Hubungan Pusat dan Daerah. Jakarta: Nusa Indah.

Suhendar, Endang.1994. Pemetaan Pola.Pola Sengketa Tanah di Jawa Barat. Bandung: Yayasan AKATIGA.
Fuller, Lon L. 1972. The morality of Law. Jale University Press.

Soetiknjo, Iman.1992. Politik Agraria Nasional; Hubungan Manusia Dengan Tanah yang Berdasarkan Pancasila. Yogyakarta: Gadjah Mada University Press.

Ko Tjay Sing. 1971. "Beberapa catatan tentang dan Sekitar undang-Undang Pokok Agraria." Bunga Rampai Hukum. Semarang: Fakultas Hukum Universitas Diponegoro.

Parlinidungan, AP. '1975. "Pandangan Kritis Terhadap Berbagai Aspek Dalam Pelaksanaan Undang-Undang' Pokok Agraria di Daerah Jambi." Disertasi. Yogyakarta UGM.

Ronald Z Titarelu. 1993. Penetapan Asas-asas Hukum Umum Dalam Penggunaan Tanah Untuk Sebesar-besar Kemakmuran Rakyat. Suatu kajian Filsafati dan Teoritik Tentang Pengatuan dan Penggunaan Tanah di Indonesia." Disertasi (tidak diterbitkan). Surabaya: Program Pasca Sarjana Universitas Airlangga.

Sunaryati Hartono. 1976. "Tentang Pengertian - Hak Ulayat dan Hak-hak Atas Tanah di Indonesia." Majalah Hukum Nasional. BPHN No 4. Tahun 1. 